numbers of doctors and patients at each centre, together with information on the ancillary, diagnostic, and treatment services provided. There is also a bibliography of published work describing centres and their work.

\section{Lady Tata Memorial Trust}

The trustees of the Lady Tata Memorial Trust for research in leukaemia have made the following awards for the academic year 1971-2: G. B. Rossi, Rome (fellowship, in second year); J. F. Doré, Paris (expenses grant, renewed for third year); T. J. E. Rytomaa, Helsinki, and B. Szafarz, Paris (expenses grants, renewed for second year); T. M. Dexter, Manchester (whole-time scholarship, renewed for second year).

\section{B.M.S.A. Symposium}

The British Medical Students' Association will be holding a symposium entitled, "Health Services for Great Britain" at the Medical School, Edgbaston, Birmingham, on the afternoon of Friday, 2 July, and on Saturday, 3 July. Details can be obtained from Mr. A. Murray, Symposium Committee, Q.M.M. Room, The Medical School, Edgbaston, Birmingham 15.

\section{Programmed Learning}

A second edition of Programmes in the Health Sciences, a bibliography listing nearly 300 programmed texts and programmes for teaching machines in the fields of medicine, dentistry, and nursing, has been produced with assistance from the British Life Assurance Trust. The bibliography is available from N.C.P.L. Publications, School of Education, P.O. Box 363, University of Birmingham, Birmingham B15 2TT, price $60 \mathrm{p}$.

\section{People in the News}

Mr. Robert V. Cooke, senior vice-president of the Royal College of Surgeons and a past president of the B.M.A., has been made sheriff of Bristol.

Dr. J. Jancar, consultant psychiatrist, Stoke Park Hospital, Stapleton, Bristol, has been awarded the second Burden research medal and prize for outstanding research work in he field of mental subnormality.

\section{COMING EVENTS}

Medical Association for Prevention of War.Conference, "Problems in Communication," 9-11 July, Newnham College, Cambridge. Fee £7.50 (medical and dental students £4), inclusive.

Applications before 23 June and details are obtainable from Mrs. K. MacSorley, 238 Camden Road, London N.W.1.

"Management of the Gravely III Cardiac Patient."-Third international symposium on current aspects of cardiology arranged by the Institute of Cardiology, 30 June-1 July, Royal College of Physicians of London. Fee \&20. Details from the dean, Institute of Cardiology, 35 Wimpole Street, London W1M 8EX. (Tel. 01-486 3043.)

King Edward's Hospital Fund for London.Talk, "Priorities in Health Care," by Professor T. McKeown, 6 July, 12.15 p.m., London W.1.
Fee $\mathscr{1} 1$ (including lunch). Applications to the director, Hospital Centre, 24 Nutford Place, London W1H 6AN.

Biochemical Society.-Meeting, 8-9 July, Oxford University. The programme includes colloquia on "Somatic Cell Genetics," "New Sources of Protein Foods," and "Steroids and Chromatin." Details from the society, 7 Warwick Court, High Holborn, London WC1R 5DP. (Tel. 01-242 1076/7).

\section{SOCIETIES AND LECTURES}

For attending lectures marked * a fee is charged or a ticket is required. Applications should be made Monday, 21 June

INSTITUTE OF DeRMatologY. -4.30 p.m., Dr. A. Herxheimer: Evaluation of Drugs in Dermatology.
INSTITUTE OF LARYNGOLOGY AND OTOLOGY. -5.30 p.m., combined consultation clinical meeting.

Tuesday, 22 June

Institute of Dermatology.-4.30 p.m., Dr. E. M. Jepson: Xanthomatosis.

Ring's COLlege HoSPITAL MEDICAL SCHOOL.-5.30 Automation.

ST. BARTHOLOMEW'S HoSPITAL. -5 p.m., Mr. A. W. cocialist Cervical Spine in Rheumatoid Arthritis. Commons (room 10), 7.30 p.m., teach-in: N.H.S
Commons Commons (room 10), 7.30 p.m., teach-in: N.H
Dentistry at the Crossroads or in a Cul-de-sac.

Wednesday, 23 June

Royal College of Surgrons of England.-5 p.m., Arnott demonstration by Miss Jessie Dobson: An
Account of the Life and Work of Percivall Pott.

Royal Free Hospital.-5.15 p.m., Dr. R. L. Peters (Los Angeles): Sclerosing Hyaline Necrosis of the

Royal Postgraduate Medical School.-2 p.m., Professo

Royal Society of Medicine.-5.30 p.m., Professor ROYAL SOCIETY OF MEDICINE. -5.30 p.m., Professor
T. Symington: A Look at Problems of Endocrine Gonadal Tumours.

Thursday, 24 June

St. Mary's Hospital Medical School.-5.15 p.m Mr. D. J. MacRae: Clinical and Endocrinological
Aspects of Dysmaturity.

Friday, 25 June

Charles Burns Clinic, Birmingham.-At Queens bridge Road, Moseley, 4 p.m., Dr.

NewCastle UPON TyNe Regional NeURologicai CENTRE.-AT Newcastle General Hospital, 5.30 CENTRE.-At Newcastle General Hospital, 5.30
D.m., Dr. A. J. McComas, Mr. J. Hankinson, Dr. D.m., Dr. A. J. McComas, Mr. J. Hankinson, Dr. physiological Studies on the Human Thalamus.

Royal Postgraduate Medical School.-11 a.m. Research in Progress meeting.

\section{APPOINTMENTS}

Birmingham Regional Hospital BoARd.-S. D Sarker, M.B., F.R.CS. (consultant traumatic and orthopaedic surgeon, West Bromwich and South Birmingham group); N. E. Brown, M.B., D.O., F.R.C.S group); M. Monro, M.D., D.P.M. (consultant psvgroup); M. Monro, M.D., D.P.M. (consultant psv
chiatrist, Wolverhampton County Bo-ough Council and the Wolverhampton group); C. Chacon, L.A.H. D.P.M. (consultant psychiatrist. Wolverhampton
group); C. Cheyne, M.B., M.Ch.Orth., F.R.C.S. group); C. Cheyne, M.B., M.Ch.Orth., F.R.C.S. and South Birmingham groups); J. W. Partridge, M.B., M.R.C.P., D.C.H., D.Obst.R.C.O.G. (consulRoad (Birmingham) groups); M. Quasim, M.B. M.R.C.P., D.P.M. (consultant psychiatrist, Burtonon-Trent and Coventry groups); F. P. Vince, M.B. ence in clinical endocrinolooy), Coventry group); P. anaesthetist, Stafford group); J. A. Prosser, M.B., cestershire and South Birmingham groups); J. H Morris, M.B. D.P.M. (consultant child psychiatrist, South and Mid-Worcestershire groups); G. Kitchen M.R.C.S., F.F.R., D.M.R.T. (consultont radiotherapist, Dudley and Stourbridge and Wolverhampton
groups); A. C. P. Sims, M.B., D.P.M. (consultant psychiatrist, Dudley Road (Birmingham) groups); L. (with special experience in nuclear medicine), Dudley Road (Birmingham) groups); R. C. Hughes, M.B., M.R.C.P. (consultant neurologist, Wolverhampton Tooth, M.B., M.R.C.O.G groups); Elisabeth A. and McCourt, M.B., F.F.A., R.C.S group); K. J. G. thetist, Wolverhampton group); W. G. B Clark, M.B., F.F.A., R.C.S. (consultant anaesthetist, North Birmingham group); J. M. Mynors, M.B., Ch.M. L. Francis, M.B., M.R.C.P. (consultant physician, mid-Staffordshire group); I. A. Harper, M B., M.R.C.Path. (consultant bacteriologist, Wolverhamp(consulap); G. P. Xifaras, M.D., F.F.A., R.C.S. group); J Moore, M B M R P Birmingham) (consulYoung, M.B., D.P.M (consultant psychiatrist J. D. Staffordshire. group); N. StJ. P. Dwyer, MidF.R.C.S. (consultant in traumatic and orthopaedic surgery, East Birmingham group); R. F. Gunstone, B.Sc., M.B., M.R.C.P. (consultant physician (with special experience in infectious diseas $(s)$, Coventry group); B. S. Smith, M.B., M.R.C.P.' (consultant physician, West Bromwich group).

MANCHESTER REgional HOSPITAL BOARD.-G. J. pockley, M.B., M.R.C.P.Ed.; D.P.M. (consultant M.R.P. Prestwich Hospital); T. N. Miller, B.M., Glossop group); D. R. Shreeve, M.B., M.R.C.P. (consultant physician, North-east Manchester group); I. J. Kerby, M.B., F.F.R., D.M.R.T. (consultant radiotherapist, Christie Hospital and Holt Radium Institute) ST. Mary's Group OF Hospitals, LONDON.-Mary
E. Carter, M.D., M.R.C.P.Ed. (consultant in physical medicine and rheumatology). UNITED BIRMINGHAM Hospitals.--D. R. London,
D.M., M.R.C.P. (consultant physician).

\section{UNIVERSITIES AND COLLEGES}

ROYAL COLLEGE OF GENERAL

TIONERS

The following successful candidates have been R. Abendstern, M. J. Aylett, J. Beard, P. M Berry, R. Bond, J. E. Botha, J. M. Brown, P. E R. D. R. M. Butler, D. J Cohen, K. Fairweather, R. A. S. Gilchrist, N. S. Halabi, $R$ (with distinction), Humphrey, D. A. Hyslop, B. J. Ireland, B. M. Jones, J. Kelly, D. M. D. Lambert, R. A. A. R. Lawrence, R. M. H. Lefever, Maj. I. A. Lonewill, A. D. Milne, W. J. Montgomery, G. M. Morris, M. Noel, A. DeR. N'Yeurt, B. Ölsburgh, W'. M. Patterson, J. B. Pitt, F. J. Porter, D. S. Rainey, J. O. Simpson, R. R. Smith, J. R. Sneddon, M. D. B. Stephens, F. I. Stewart, J. Thomas, Trimble, R. J. Tucker, D. Ward Smith, M. J. Wright.

\section{CORRECTIONS}

M.R.C.P.

We regret that the name of Dr. Upendra Acharya was omitted from the list of those elected Members of the Royal College of Physicians of the United Kingdom (22 May, p. 480 ).

The Satchel and the Shining Morning Face In the article by Dr. R. Gibson (5 June, p. 549 ) we regret a printing error in the penultimate paragraph on page 551 . This should have read ". . . his present moods are transitory."

\section{Notice to Authors}

When original articles and letters for publication are not submitted exclusively to the British Medical fournal this must be stated.

Correspondence on editorial business should be addressed to the Editor, British Medical fournal B.M.A. House, Tavistock Square, London WCIH 9JR. Telephone: 01-387 4499. Telegrams: Aitiology, London, W.C.1.

Authors wanting reprints of their articles should notify the Publishing Manager, B.M.A House, Tavistock Square, WC1H 9JR, on receipt of proofs. 